\title{
Norges fjelde - og den naturvidenskabelige proces
}

Af Søren B. Nielsen, Geologisk Institut, Aarhus Universitet

Geologi er en krævende naturvidenskabelig disciplin, bl.a. fordi det er en udfordring med den menneskelige erfarings korte tidshorisont at forholde sig til de millioner af år geologiske processer har til deres rådighed. En million år er så lang tid at meget kan nå at ske, men modsat kan der også ske ingenting, og stort set ingenting, bortset fra lidt erosion og flytten rundt på produkterne, kan fortsætte med at ske gennem yderligere mange millioner år. Under så vanskelige erkendelsesmæssige forhold er det godt at have den naturvidenskabelige metode til sin rådighed.

Det er kernepunktet i den naturvidenskabelige arbejdsmetode at foretage observationer for at afprøve hypoteser om hvordan naturen fungerer. Skulle observationerne nemlig være i modstrid med hypotesens forudsigelser, må hypotesen forkastes og en ny formuleres. Er omvendt hypotesen konsistent med observationerne, ja så er den faktisk ikke "sand", men netop blot konsistent med observationerne. Det er nemlig ganske givet at der senere vil vise sig en ny type observationer eller nogle mere nøjagtige målinger der kræver en yderligere nuancering af hypotesen, eller endog dens forkastelse.

Den veletablerede hypotese vs. den nye I denne proces bliver kulturen efterhånden klogere, men det er mest synligt i det lange perspektiv, for ovenstående beskrivelse af hvorledes bedre hypoteser i en udelukkende rationel proces oprettes på ruiner af aflagte, glorværdige hypoteser ser man ikke altid ved en betragtning af forskningens virkelighed. Her kræver et hypoteseskift ofte intet mindre end de ældres pensionering og at en ny generation ser sagen $i$ et nyt lys, for forskere er jo mennesker af kød og blod som af nødvendighed må være identiske med deres hypoteser, som jo ikke er andet end menneskers (ofte særdeles kløgtige) tankespind.

Den naturvidenskabelige metodes i teorien velsmurte maskineri hoster derfor

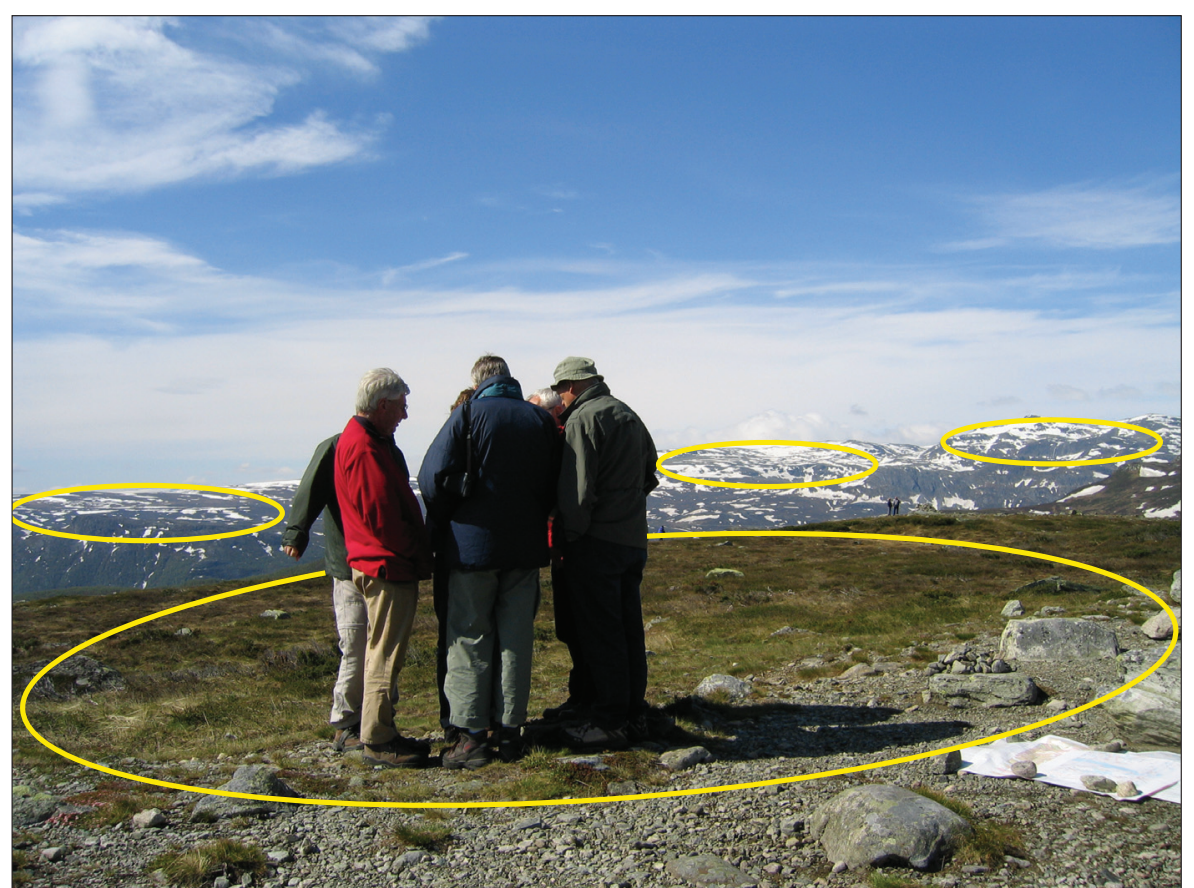

Geologer og geomorfologer og davisiske fladefragmenter (ellipserne) i Sydnorges højland. (Foto: Forfatteren)

en smule når en ny hypotese prikker en veletableret hypotese på skulderen og trænger sig på. Den etablerede hypoteses forkæmpere lader sig ikke fra det ene øjeblik til det næste overbevise om noget andet: tværtimod, de er identiske med deres hypotese (de lever af den), og den naturlige reaktion på eksistenstruende udfordringer (den eventuelle udsigt til manglende forskningsbevillinger) er at forsvare sig. Man kan måske sige at der på denne måde er indbygget en vis sikkerhed i processen for at gode hypoteser ikke ved en tilfældighed forkastes.

\section{Den veletablerede hypotese}

Denne hypotesernes brydning ser man for tiden for fuld udblæsning omkring den geologiske forståelse af de norske fjeldes og den østlige Nordsøs (Danmarks) senere historie. Den norske fjeldkæde er en del af den kaledoniske foldning der fandt sted $i$ silur tid (443-417 mio. år) og hvis reminiscenser man i dag ser også i Skotland, Nordøstgrønland og på Svalbard. Den veletablerede hypotese er her det synspunkt at de norske fjelde har været borteroderet og stort set overskyllet af kridthavet for først relativt sent i løbet af Kænozoikum, og med accelererende hast gennem Neogen, igen at være blevet hævet til deres nuværende højde. Hævningsfænomenet skal også have påvirket den østlige Nordsø, der er blevet vippet med hævning mod nordøst og indsynkning mod sydvest. Hypotesen om den neogene hævning af de norske fjelde og kystområderne er blot en brik i en mere omfattende hypotese der ser en globalt korreleret neogen hævning af bjergområder forskellige steder på kloden (beskrevet i Hay et al. (2002) samt i Molnar (2004)). I nærværende artikel vil vi fokusere på vort lokale eksempel og se hvorledes hypoteserne brydes her.

Den veletablerede hypotese benytter følgende argumenter for at understøtte eksistensen af den neogene tektoniske hævning:

1. I tidlig Oligocæn afløses den stilfærdige paleocæne og eocæne sedimentation af smektitholdig mergel i det østlige nordsøområde af voluminøse prograderende, grovere og glimmerholdige sedimenter af skandinavisk oprindelse. Man kan nemt forestille sig at netop noget sådant ville ske hvis Sydnorge begyndte at hæves med erosion til følge.

2. Analyse af fissionsspor (se på næste side) i apatit fra prøver af grundfjeldet i Sydnorge 
viser en øget erosionsrate gennem Neogen. Dette ville være den oplagte konsekvens hvis Sydnorge blev hævet på dette tidspunkt.

3. Sedimenter langs den norske kyst og i den østlige Nordsø udviser stigende overbegravelse ind mod kysten, dvs. sedimenterne er væsentligt mindre porøse end de burde være ved deres nutidige begravelsesdybde. Konklusionen er at de nu befinder sig i en hævet position i forhold til en tidligere dybere begravelse, og at hævningen har medført erosion af overliggende sedimenter - et oplagt tegn på at hævning af baglandet har påvirket også de kystnære sedimenter.

4. Flere steder i Norges højland ser man relativt flade områder (fx Hardangervidda), og i mange fjeldområder synes afskårne flade toppe at definere en imaginær flade af større udstrækning. Ifølge Davis' (18501934) teori om landskabers udvikling kan et sådant landskab forklares ved at et peneplan tidligere blev dannet ved erosion til havniveau for senere at blive hævet til en højere position med dannelse af dybt nedskårne dale til følge, men altså også sine steder bevarelse af det oprindelige flade landskab. Den norske geolog Hans Reusch (18521922) fandt at denne model passede fint på det norske fjeldlandskab, og den er fortsat et centralt element i den neogene hævningshypotese.

Der er således vægtige argumenter for den neogene hævningshypotese, men hvad har forårsaget hævningen, for den kan ikke være sket ved de klassiske mekanismer der består $\mathrm{i}$ at fortykke skorpen gennem forkortning (bjergkædefoldning) eller ved at intrudere kilometertykke lag af magmatiske bjergarter. Det er nemlig karakteristisk, og med til at gøre den interessant, at den neogene hævning er foregået uden forkastningsaktivitet og uden intrusion af gangbjergarter af kænozoisk alder.

Den nye: Erosions- og isostasihypotesen Hypoteser med interessante problemstillinger tiltrækker forskere, og således lod også

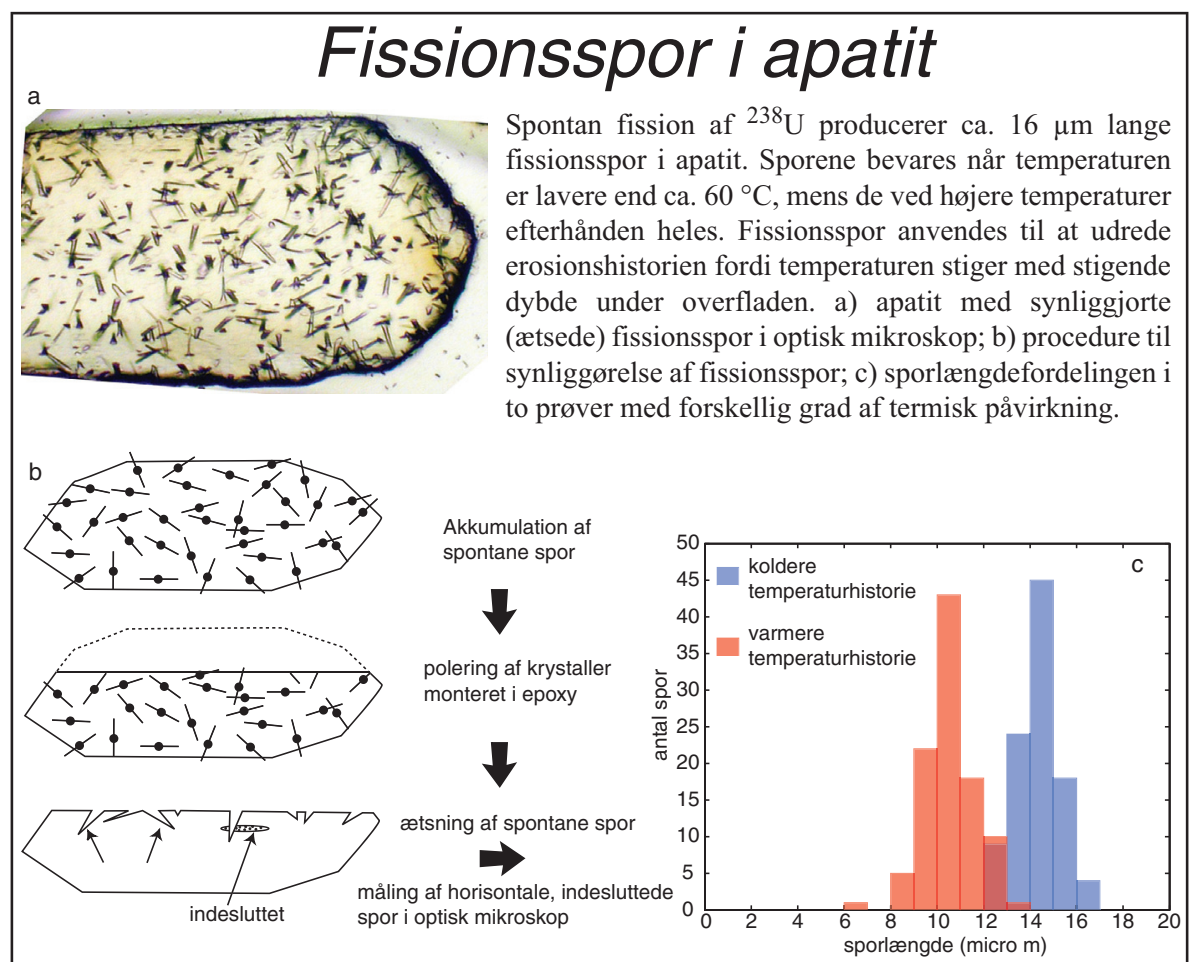

grupper af forskere ved Geologisk Institut Aarhus Universitet, ved Imperial College, London, og ved GFZ Potsdam, sig hverve i projekt CENMOVE under den neogene hævningshypoteses faner, først $\mathrm{i}$ håb om at indkredse og forstå den flygtige neogene tektoniske hævningsmekanisme, men siden - efter en uhildet analyse af hypotesens argumenter i lyset af nye opdagelser - med en erkendelse af at den etablerede hypotese sandsynligvis måtte afløses af en ny, nemlig den at de norske fjelde ikke har været borteroderet, men at de simpelthen er en erosionsrest af den oprindelige silure bjergkæde påvirket af skiftende klimaers eroderende virksomhed. Den nye hypotese betegnes erosions- og isostasihypotesen og er i virkeligheden et gammelt og velkendt koncept.

For at en ny hypotese kan konkurrere med den etablerede, må den i det mindste kunne forklare de eksisterende observationer og flere til samt overhovedet være bedre ved for eksempel at være simplere og ved bedre at lade sig afprøve.
Erosions- og isostasihypotesen er en bedre hypotese fordi den ved hjælp af testbare processer forklarer flere observationer end den oprindelige hypotese. Således har den neogene hævningshypotese problemer med at forklarer hvorledes den høje topografi i Norge er forbundet med et minimum i Bouguer-tyngden og stort set lokal isostatisk kompensation af topografien ved opdriften fra den skorperod som seismologiske målinger under CENMOVE har bekræftet og detaljeret eksistensen af

Dette problem er tæt knyttet til at den neogene hævningshypotese ikke kan pege på en plausibel mekanisme til at forårsage hævningen. Var nemlig topografien blevet eroderet til havniveau på et tidligere tidspunkt, ville også den opdriftsgivende skorperod være blevet elimineret (som når et isbjerg smelter fra oven), men nu er den der jo, så hvordan får man lige $10 \mathrm{~km}$ skorperod tilbage for at lave isostatisk kompenseret topografi når det ikke er tilladt at fortykke skorpen ved bjergkædefoldning eller ved at 
intrudere magmatiske bjergarter?

At erosions- og isostasihypotesen forklarer tyngdeminimummet og den lokalt kompenserede topografi i de norske fjelde er indlysende. Foldebjergkæder bliver simpelthen født med en opdriftsgivende skorperod, og det er netop dette forhold der gør at topografien kan eksistere gennem flere hundrede millioner år. Skorperoden og kravet om isostasi sørger nemlig for at sænkning af landskabets gennemsnitshøjde med $1 \mathrm{~km}$ kræver erosion af 5-6 km skorpe, hvilket med en typisk fluvial erosionsrate på $20-30 \mathrm{~m}$ pr. million år tager omkring 200 millioner år. En sænkning af den gennemsnitlige topografiske højde fra $3 \mathrm{~km}$ til $1 \mathrm{~km}$ vil altså løst anslået vare i omegnen af 400 millioner år, hvilket er et tal der minder om Kaledonidernes alder. Erosionsraten har dog selvfølgelig været højere i begyndelsen hvor relieffet var stærkere og der indimellem ( $\mathrm{fx}$ i Devon og Karbon) skete tektonisk reaktivering. Med denne model følger de norske fjelde eksemplet fra andre langtidseksisterende gamle bjergkæder som fx Great Smoky Mountains-området i Appalacherne (300 mio. år gammel og still going strong med højder over $2000 \mathrm{~m}$ ) samt foldekæden i det sydøstlige Australien.

\section{Yderligere opdagelser via CENMOVE}

For at redegøre for hvordan hypotesen om erosion og isostasi forholder sig til punkterne 1-4 ovenfor, er det nødvendigt at inddrage yderligere opdagelser fra projekt CENMOVE. Korte kerneborehuller i det østlige Jylland på tværs af Eocæn-Oligocæn-grænsen har afsløret en detaljeret korrelation mellem litologiændringer og globale klimavariationer, således at de sen-eocæne smektitiske mergelaflejringer (Søvind Formationen) fandt sted under globalt relativt varme klimatiske omstændigheder, hvorimod de siltede, prograderende og glimmerholdige aflejringer fra Viborg Formationen og dens forløber Moesgaard Formationen fandt sted under globalt koldere betingelser. Sammenhængen er overbevisende, og eftersom det er vanskeligt at forestille sig at det er litologiændringerne der driver klimaændringerne, må det omvendte være tilfældet.

Det er dog et spørgsmål hvordan klimaændringer driver litologiændringer, for der findes ikke nogen etableret global sammenhæng mellem $\mathrm{fx}$ intensiteten af nedbør og den hastighed hvormed tektonisk stabile grundfjeldsområder eroderer; det går generelt langsomt uanset hvor meget eller hvor lidt det regner. Imidlertid vil erosions- og isostasihypotesen jo implicere en lidt højere topografi på Eocæn-Oligocæn-overgangen end i dag (jo højere jo længere tilbage i tiden), og kombineres dette med den veletablerede globale afkøling er det oplagt at forestille sig at en fremvækst af bjerggletschere for alvor satte gang i erosionen $i$ de højereliggende strøg i de skandinaviske Kaledonider. Med gletscheraktivitet stiger erosionsraterne typisk en faktor 10 (og meget mere ved større gletschere) i forhold til den fluviale erosionsrate i stabile grundfjeldsområder. I dag findes mere end 1.300 gletschere dækkende et areal på ca. 2.600 $\mathrm{km}^{2}$ i de norske Kaledonider.

Til punkterne 1. og 2. ovenfor vil erosions- og isostasihypotesen altså svare at tidlig gletscheraktivitet i det norske højland formentlig kan forklare den øgede erosionsrate, og dermed den øgede sedimentproduktion, og at en sådan forklaringsmodel forøvrigt er i overensstemmelse med at den globale afkøling nu vides at være symmetrisk om polerne, og at der er fundet istransporteret sediment af eocæn-oligocæn alder i Nordatlanten hidrørende fra kælvende østgrønlandske gletschere. Der var altså store gletschere i nabolaget.

Punkt 3 kan forklares ved at pege på en væsentligt senere og langt mere dramatisk erosionseffekt fra de kvartære gletschere, der jo som bekendt har udgravet den norske rende med vanddybder på over $800 \mathrm{~m}$. Sådanne erosionskanaler (dog mindre i dybe) findes også længere mod nord på norsk sokkel, og modelleringer viser at disse kvartære erosionsfænomener er tilstrækkelige til at forklare sedimentets overbegravelse langs den norske kyst. Overbegravelsen af sedimenter i den østlige Nordsø kan ligeledes forklares ved nogen erosion af kvartære gletschere samt ved tidligere inversionsbevægelser langs Sorgenfrei-Tornquist Zonen.

Punkt 4 vedrørende oprindelsen af de flade, højtliggende områder som bevarede mesozoiske peneplaner har hidtil været problematisk at forholde sig til fordi argumentationsfølgen stort set er fuldstændigt kvalitativ. Imidlertid har fremvæksten af den kvantitative geomorfologi, med dens mulighed for at måle nutidige erosionsrater vha. kosmogene isotoper og med anvendelsen af kvantitative modeller af landskabsudviklingen over geologisk tid, åbnet nye muligheder. Det er således en kendsgerning at selv flader eroderer med en rate på 10-25 m pr. mio. år, og at fladerne således er udsat for tidens gnavende kritik og ikke bevares over længere tid. Til gengæld kan flade områder dannes i højden ved erosion til en lokalt erosionsbasis.

\section{Åben for yderligere afprøvning}

Erosions- og isostasihypotesen har således alternative, procesbaserede forklaringer på de observationer som den neogene hævningshypotese lægger til grund. I tilgift har den nemt ved at forklare sammenhængen mellem topografi, tyngdedata og graden af isostatisk kompensation, hvilket den neogene tektoniske hævningshypotese har problemer med når tektoniske hævningsmekanismer bringes i spil. Dertil kommer at erosions- og isostasihypotesen er nemmere at afprøve, for ud over geofysiske observationer som skorpetykkelse, topografi og tyngdedata inddrager den en kvantitativ

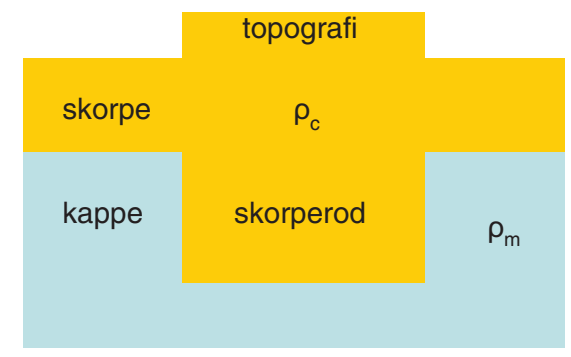

Foldebjerges høje topografi bceres $i$ henhold til princippet om isostasi oppe af en skorperod der rager dybt ned i kappen. Skorperoden bringer nyt materiale op efterhånden som topografien eroderes. For at scenke den gennemsnitlige topografi med $1 \mathrm{~km}$ skal der eroderes 5-6 km. Dette medvirker til at bjerge lever meget loenge. (Grafik: Forfatteren)

hjælpehypotese i form af klimadrevet vekslen mellem glacial og fluvial erosion i det norske højland startende i sen Eocæn.

Et sådant fænomen burde afspejles i en observerbar og detaljeret sammenhæng mellem globale klimaindikatorer, det globale havniveau, litologi og sedimentvolumen $\mathrm{i}$ Nordsøen og på norsk sokkel. Med en så mangfoldig skare af observerbare størrelser ligger erosions- og isostasihypotesen fuldstændigt åben for yderligere afprøvning.

\section{Referencer:}

Hay, W.W., Soeding, E., DeConto, R.M. \& Wold, C.N. The Late Cenozoic uplift - climate change paradox. Int. J. Earth. Science (Geol. Rundsch.) 91, 746-774 (2002).

Molnar, P. Late Cenozoic increase in accumulation rates of terrestrial sediments: How might climate change have affected erosion rates? Annu. Rev. Earth Planet. Sci. 32, 67-89 (2004).

Efter forfatterens ønske er ny kommatering anvendt $i$ denne artikel! 